NBER WORKING PAPER SERIES

\title{
NETWORKING FRICTIONS IN VENTURE CAPITAL, AND THE GENDER GAP IN ENTREPRENEURSHIP
}

\author{
Sabrina T. Howell \\ Ramana Nanda \\ Working Paper 26449 \\ http://www.nber.org/papers/w26449 \\ NATIONAL BUREAU OF ECONOMIC RESEARCH \\ 1050 Massachusetts Avenue \\ Cambridge, MA 02138 \\ November 2019
}

We thank Louis Maiden for exceptional research assistance. We are extremely grateful to Jodi Gernon for her feedback and support, and to Catherine Cronin, Nick Janini, Julia Kemp, Samantha Snyder and Coral Sullivan for their help with providing us data. We also thank Tom Eisenmann, Michael Ewens, Rem Koning, Rick Townsend and the seminar participants at the Kauffman Foundation Entrepreneurship Scholars Conference for helpful comments. Howell thanks the Kauffman Foundation and especially Sameeksha Desai for generous support. Nanda acknowledges support from the Division of Research and Faculty Development at Harvard Business School. The views expressed herein are those of the authors and do not necessarily reflect the views of the National Bureau of Economic Research.

NBER working papers are circulated for discussion and comment purposes. They have not been peer-reviewed or been subject to the review by the NBER Board of Directors that accompanies official NBER publications.

(C) 2019 by Sabrina T. Howell and Ramana Nanda. All rights reserved. Short sections of text, not to exceed two paragraphs, may be quoted without explicit permission provided that full credit, including $(\odot)$ notice, is given to the source. 
Networking Frictions in Venture Capital, and the Gender Gap in Entrepreneurship

Sabrina T. Howell and Ramana Nanda

NBER Working Paper No. 26449

November 2019

JEL No. D83,D85,G24,J16,L26

\begin{abstract}
Exploiting random variation in the number of venture capitalist (VC) judges assigned to panels at Harvard Business School's New Venture Competition (NVC) between 2000 and 2015, we find that exposure to more VC judges increases male participants' chances of founding a VC-backed startup after HBS much more than this exposure increases female participants' chances. A survey suggests this is in part because male participants more often proactively reach out to VC judges after the NVC. Our results suggest that networking frictions are an important reason men benefit more than women from exposure to VCs. Such frictions can help explain part of the gender gap in entrepreneurship, and also have implications for how to design networking opportunities to facilitate financing of the best (rather than just the best networked) ideas.
\end{abstract}

Sabrina T. Howell

NYU Stern School of Business

KMC 9-93

44 West 4th Street

New York, NY 10012

and NBER

showell@stern.nyu.edu

Ramana Nanda

Harvard Business School

Rock Center 317

Soldiers Field

Boston, MA 02163

and NBER

rnanda@hbs.edu 


\section{Introduction}

Venture capital (VC) is a crucial financing source for new ideas and technologies (Kaplan \& Lerner 2010, Gornall \& Strebulaev 2015). Yet a relatively small number of VC firms and their investing partners account for a disproportionate share of the capital that VCs deploy. Frictions in the process through which these gatekeepers select and advance new ideas can have consequential effects on the types of ideas that are commercialized in the economy (Kerr, Nanda \& Rhodes-Kropf 2014).

One concern related to the role of VCs as gatekeepers is the gender disparity in VC-backed entrepreneurship. While women's career trajectories differ from men's across a number of fields (Bertrand, Goldin \& Katz 2010, Goldin, Kerr, Olivetti \& Barth 2017), the gender gap is especially severe in VC-backed entrepreneurship. Levine \& Rubinstein (2017) find that women comprise only 28 percent of the incorporated self-employed. Gompers \& Wang (2017) show that only 10-15 percent of VC-backed startup founders are women. A growing literature, including Becker-Blease \& Sohl (2007), Scott \& Shu (2017), Gornall \& Strebulaev (2018), and Ewens \& Townsend (2019) has documented the gap and aimed to characterize frictions that might lead to it. In particular, this work suggests that the gap originates early in the startup lifecycle, at or near the moment of founding. From an economic perspective, the gap is particularly worrying if it reflects systematic gender-related frictions causing high-quality entrepreneurs or ideas to go unfunded.

In this paper, we examine a particular channel that might be important for the gender gap in VC-backed entrepreneurship: networking-frictions. It is widely known that faceto-face connections and trusted referrals are important, if not primary, deal sourcing methods for many top VC investors. This reliance on personal networks may be the

result of extreme information asymmetry between founders and VC investors (e.g. Stuart \& Sorenson 2005, Hochberg, Ljungqvist \& Lu 2007, Kerr \& Mandorff 2015). However, 
heavy reliance on trusted referrals may also privilege those who are more connected to investors (Cohen, Frazzini \& Malloy 2008). Since over 90 percent of VC investors are men (Gompers \& Wang 2017), homophily in networking could disproportionately impact women if entrepreneurs do not get a chance to interact as much with VCs of their own gender without an introduction.

In light of the established facts that women founders receive less VC investment and personal connections are central to the $\mathrm{VC}$ deal sourcing process, it is possible that exposing early stage female entrepreneurs to more networking opportunities with VCs could help reduce the gender gap. That is, exposure to more VCs could help compensate for any baseline advantages that men have in meeting VCs. However, rigorously studying network-related information frictions is challenging. Social networks are endogenous, making it hard to separate the role of networking frictions from unobserved variables, such as whether an entrepreneur's business model is a good fit with VC.

We address this empirical challenge by employing exogenous variation in exposure to VC networks at Harvard Business School's (HBS) New Venture Competition (NVC). The NVC is Harvard's flagship new venture competition and a key gateway to VC-backed entrepreneurship after HBS. Many successful founders, including those of 'unicorn' startups, have been participants in the NVC. Gompers \& Wang (2017) note that among business schools, HBS accounts for the largest number of graduates that receive VC funding; the next-largest in terms of VC backed entrepreneurs is Stanford GSB, which has half as many alumni who are VC-backed entrepreneurs. HBS therefore provides an important and interesting setting to study determinants of the gender gap in high-growth entrepreneurship.

In the first round of the NVC, each team is assigned to one of about 15 panels, each composed of about six judges. Having delivered a pitch to the judges and answered their questions, the participants are in a position to reach out to judges after the competition, leveraging the connection to ultimately raise $\mathrm{VC}$ financing for their ventures. The 
competition does not, however, explicitly encourage such follow-up.

Our research design exploits random variation in the number of VC judges across panels, which arises from the way in which judges are allocated to panels in the NVC. Our core empirical specification estimates the differential effect of having an additional VC judge on the panel for a male participant's subsequent chances of VC-backed entrepreneurship relative to a female participant's chances of VC-backed entrepreneurship. Isolating the interaction between a participant's gender and exposure to a larger number of VCs on a panel enables us to distinguish effects stemming from random differences in exposure to VCs from channels related to fixed differences between men and women in their demand for VC financing, or the degree to which businesses founded by women are a good fit with VC financing.

If lack of exposure to VCs among female participants were an important friction, we would expect to find that on the margin, exposure to an additional $\mathrm{VC}$ on a panel would be more valuable to female participants. However, we find the reverse. The raw relationship shown in Figure 1 indicates that exposure to more VCs substantially benefit male participants, while this relationship is at most only marginally positive for women. Regression estimates find that relative to the effect among women, each additional VC judge on a panel increases the likelihood of men starting a VC-backed company after HBS by 25 percent. Placebo tests show that the result is not present among participants starting ventures with no VC financing or participants joining VC-backed startups as employees. Finally, judges on the panel in the same sector as the participant or with backgrounds besides VC, such as corporate executives, lawyers or academics, have no differential effect by gender on VC-backed entrepreneurship (nor do they have an independent effect).

The results are robust to controlling for a number of individual characteristics such as venture sector, college major, stated interest in entrepreneurship when entering HBS, and entrepreneurship experience prior to attending HBS. Such covariates are known to 
be correlated with VC-backed entrepreneurship but are typically unobserved. While our estimation strategy does not require such person-level controls, they are useful for precision and establishing the robustness of our research design. Our main estimates also include a variety of competition controls, such as the number of ventures on the panel, the score the venture received, and whether the venture won. Finally, the results are robust to including panel fixed effects.

Why might exposure to VCs compound the gender gap rather than reduce it? To shed light on the mechanism, we rely on survey evidence from NVC participants. The survey responses reveal that male participants are nearly twice as likely as women to proactively reach out to VC investors after the NVC. Conditional on reaching out, however, men and women report no difference in the rate at which VCs respond to their outreach or any difference in the degree to which VCs proactively reach out to them. ${ }^{1}$ Each individual outreach to an investor by an entrepreneur obviously has a small chance of being ultimately valuable in terms of raising VC, but a fixed difference in the likelihood of outreach between men and women compounds across the number of VCs on a panel, making the difference in the benefit larger for panels with more VCs than those with fewer. ${ }^{2}$ Consistent with this, qualitative responses in the survey also suggest that because follow-up with judges at the NVC was not explicitly encouraged, women were more likely to have some reservation about leveraging the connection to discuss fundraising.

We do not find obvious evidence of explicit bias by male VCs against female participants in our sample. In addition to VCs responding to outreach equally by participant gender, we show that the private scores of VC judges are in fact slightly

\footnotetext{
${ }^{1}$ These survey results are consistent with Gornall \& Strebulaev (2018), who run a large-scale field experiment to document that VCs do not seem to be biased in responding to female entrepreneurs.

${ }^{2}$ As a simple example, suppose that men are twice as likely to reach out to all investors on their panel, and each initiation leads to a 1 percentage point chance of VC-backed entrepreneurship post HBS. On a panel with $2 \mathrm{VCs}$ the difference would be 2 percentage points, but in a panel with 5 VCs the difference would be 5 percentage points. Assuming an identical 10 percent baseline entry rate, this would imply that going from a panel with 2 VCs to a panel with 5 VCs increased the relative probability of VC-backed entrepreneurship for men by 30 percent.
} 
lower for male-led ventures than for women-led ventures. Also, while there are too few female VC judges to establish precise effects by judge gender, we do not find evidence that female VC judges are differentially beneficial for woman participants. However, less observable discrimination may be at play and the lack of outreach by women could reflect expectations of bias or harassment.

While our analysis is based on a sample that is quite particular, we believe the results have broader significance. If networking frictions matter in this already highly ambitious and well-connected sample of potential entrepreneurs, it seems likely that they will matter more generally in VC and thereby perhaps contribute to the overall gender gap in VCbacked entrepreneurship. In particular, they suggest that structural solutions that focus only on providing female entrepreneurs more exposure to VCs may not always be sufficient to eliminate such networking frictions.

Our results are related to evidence about the gender gap in science, invention, and entrepreneurship. ${ }^{3}$ There is a small but growing literature looking more closely at frictions that might lead to systematic gaps in VC funding for new ventures, independent of the quality of ideas. This prior work has focused more on the role of preferences or discrimination on the part of investors in driving some of the gender gap in entrepreneurship. Two recent papers are especially related. First, Ewens \& Townsend (2019) use data on startups that seek funding on AngelList to find evidence that angel investors to prefer to invest in founders of their own gender. Second, Gornall \& Strebulaev (2018) experimentally send pitch emails from startup founders to angel and VC investors. They find no evidence of discrimination at this contact stage. While both these papers focus on entrepreneurs seeking funding, our approach sheds light on the stage before explicit fundraising, where most of the gap between women and men in high-growth entrepreneurship seems to originate. For example, Ewens \& Townsend

\footnotetext{
${ }^{3}$ This includes Brooks et al. (2014), Reuben, Sapienza \& Zingales (2014), Hengel (2017), Bell et al. (2018), and Cook, Diamond, Hall, List \& Oyer (2018).
} 
(2019) note that just 16 percent of founders seeking financing on AngelList are women.

It is worth emphasizing that there are many potential reasons why women might not seek or receive $\mathrm{VC}$ proportionately to their share of the population, and these reasons are not mutually exclusive. For example, women may more often perceive family obligations to be incompatible with leading a high-growth startup . Alternatively, women may be more likely to found ventures in industries in which VCs tend not to invest. Women may also face discrimination in ways that we do not observe. Some of these explanations have been explored in a broader context in Bertrand et al. (2010), Bertrand (2013), Castillo et al. (2013), Pew (2013), Pew (2015), Bertrand, Kamenica \& Pan (2015), Fang \& Huang (2017), and Goldin et al. (2017). Women have also been shown to be more risk averse than men (e.g. Barber \& Odean 2001, Niederle \& Vesterlund 2007, Sapienza, Zingales \& Maestripieri 2009). Our goal is not to address these potentially profound, populationwide explanations. Instead, we focus on evaluating a specific friction conditional on an individual demonstrating serious interest in high-growth entrepreneurship.

One advantage of this focus is that it has immediate implications for new venture competitions and accelerators, which can potentially design networking between entrepreneurs and investors to facilitate the financing of the best (rather than just the best networked) ideas. In particular, our results point to benefits from encouraging and potentially formalizing networking opportunities between individuals, rather than assuming that people will contact each other independently.

\section{Data}

Before moving to the analysis, we describe the HBS NVC and the data from it that we employ in our analysis (Section 2.1). We discuss the HBS administrative and career history data. Section 2.4 explains the survey design in Sections 2.2 and 2.3. 


\subsection{HBS NVC data}

The NVC is a startup "pitch" competition in which founders present their business ideas to expert judges. A team must have at least one current HBS student to participate. The NVC promotes itself as an opportunity for students to "put entrepreneurship principles into practice," to receive feedback on their ideas, and to get exposure to key stakeholders in the entrepreneurial ecosystem. There is also a cash prize for the ultimate winner and runners up in the competition. This type of business plan competition is now a standard component of many undergraduate and MBA programs, and is also a common stepping stone in an early stage startup's life, particularly for first-time founders and student entrepreneurs (Howell 2019).

The NVC started in 1997 with a business track. It added a social enterprise track in 2001 and an alumni track in 2010. The core dataset for our analysis consists of comprehensive team and judging information for the business track between 2000 and 2015 (except for 2003, for which no data are available). ${ }^{4}$ The competition has three rounds, but our analysis focuses on the first round, in which teams and judges are assigned to parallel sessions that run roughly simultaneously in separate rooms. ${ }^{5}$ Judges formally score the pitches of participating ventures, and these scores determine which ventures proceed to the next round of judging. Each team's pitch and question period lasts only about 15 minutes, but there are opportunities for follow-up by a proactive student or judge. This follow-up could occur at the cocktail hour after the pitch

\footnotetext{
${ }^{4}$ We do not consider participants in the social enterprise track for this analysis because of the potential mismatch between the goals and business models of such ventures and the objectives of for-profit venture capital investors. The alumni tracks are run by local alumni chapters, making the data inconsistent and hard to gather.

${ }^{5}$ The value of the cash prize and the number of runner up teams getting a prize has changed over time, but the structure of the judging - which forms the basis of our empirical strategy - has not changed during the period we study. Specifically, in 1997, the winning team at the business plan competition was awarded $\$ 10,000$ and 3 runner-up teams were each awarded $\$ 5,000$. In 2009, the winning team's award was changed to $\$ 25,000$ and 2 runner teams shared $\$ 10,000$ each. In 2013 , the winning team received $\$ 50,000$ and one runner up team was awarded $\$ 25,000$. The cash prize for the winning team was raised to $\$ 75,000$ in 2017 , but this change was outside of our sample period. Also, the competition was re-branded from the HBS "Business Plan Competition" to the HBS "New Venture Competition" in 2013.
} 
sessions, or privately if the student or judge requests contact information directly or from HBS NVC administrators.

Several elements make the NVC's first round an attractive setting to explore the role of gender in early stage, high-growth entrepreneurship. First, participants not only demonstrate a revealed preference for joining the labor force (by virtue of attending business school), but also demonstrate an interest in pursuing high-growth entrepreneurial activity. Startups founded by HBS alumni have gone on to raise substantial amounts of venture capital. For example, one analysis of Pitchbook data found that "1,069 HBS MBAs have founded 961 companies that have raised $\$ 22.4$ billion in VC [..] Entrepreneurs from HBS have founded 13 unicorns — nearly double its closest competitor, Stanford." ${ }^{6}$ Among U.S. business schools that focus on entrepreneurship, HBS has among the largest student bodies and thus offers a substantial sample for study, even when the sample is restricted to NVC participants. ${ }^{7}$

Second, as we elaborate below, our research design assesses how random variation in the number of VC judges across panels impacts VC-backed entrepreneurship after HBS. This enables us to overcome the challenge that exposure to VCs is typically nonrandom and unobserved, making it hard to effectively study networking frictions in VCbacked entrepreneurship. Beyond the research design, we observe individual and venture characteristics that, while not needed for identification, provide reassurance about the mechanism we document in our analysis. For example, we observe a venture description that allows us to categorize ventures by sector. Of particular note is our access to the scores that judges assign to team. These data are private, so participants never observe their own or other teams' scores. Judges score independently and observe only their own

\footnotetext{
${ }^{6}$ Examples of these "unicorns" include health insurance company Oscar, fashion rental company Rent the Runway, and video game producer Zynga. (See https://www.businessbecause.com/news/mbaentrepreneurs $/ 4183 /$ harvard-startups-rake-in-venture-capital.)

${ }^{7}$ In 2017, U.S. News ranked HBS the third best MBA program for entrepreneurship, and it has more than double the annual enrollment of any other program in the top five (See https://www.usnews.com/best-graduate-schools/top-business-schools/entrepreneurship-rankings).
} 
scores, and never a venture's overall rank. The private scores enable us to control for a measure of venture quality when conducting our analysis.

To participate in the NVC, a founding team must have at least one member who is a current HBS MBA student. About 70 percent of participants are HBS students; other participants are mostly students elsewhere at Harvard, and a minority are students at other universities or recent graduates. We restrict our sample to the 964 unique participants who are HBS students at the time of the competition, because these are the students for which we have a rich set of covariates that are typically unobserved, as well as comprehensive outcome data post-graduation. As Table 1 Panel A shows, 32 percent of the participants are female, which is only slightly smaller than their share of the overall HBS population. ${ }^{8}$ The participants are members of 647 teams, each of which has 2.5 members on average. Table 1 Panel B shows that average team sizes for female and male participants are quite similar. Across all years in our data, there are 573 unique judges, of which 243 are VCs. Some judges participate in multiple years. Each panel has on average six judges, as shown in Table 1 Panel E. Just over half of judges on a panel are VCs on average, though this can and does vary substantially due to the way in which the allocation of judges is done.

\subsection{HBS administrative data}

Working with the staff at the HBS MBA program and alumni office, we were able to create an anonymized but individual level dataset that includes information on student backgrounds and interests while they were at HBS. Specifically, we matched each of the 964 students in our sample to administrative data from HBS on the candidate's gender, an indicator for being a U.S. citizen, and indicators for having an undergraduate degree

\footnotetext{
${ }^{8}$ The 36 percent of HBS graduates who are women is slightly less than the 43 percent in 2006 across all MBA programs, but higher than the 26 percent of Chicago Booth MBAs between 1990 and 2006 that were women (Bertrand et al. 2010).
} 
in computer science, engineering, and economics, business or management. Additional controls include attending an undergraduate university that was in the Ivy League or was MIT, Stanford or Caltech, having founded or co-founded a company prior to HBS, having worked at a VC-backed startup prior to HBS and having worked at a VC firm prior to HBS. We also include indicators for the student having self-identified as having a personal or professional interest in entrepreneurship, or being involved in entrepreneurship or VC clubs at HBS.

As we explain below, our empirical design exploits random variation in the number of VCs across panels. Nevertheless, the rich set of individual characteristics are valuable as they help us further control for any differences in interests, skills and experience related to VC-backed entrepreneurship that may be correlated with the participant's gender, factors that are typically unobserved in most studies examining the gender gap in entrepreneurship. This allows us to verify the validity of our identification assumption, as our estimates remain quite stable with the inclusion of these additional covariates.

\subsection{Career histories}

Working with the staff at the HBS alumni office, we created an anonymized but individuallevel panel dataset of career histories for each NVC participant. Our data include the names of the organizations at which they worked, their titles at each organization, and the years associated with each position. We use the titles to define whether an individual was a founder or co-founder of a business, and we determine if the startup received VC by looking for a match to the firm's name and location in two databases of VC portfolio companies: CB Insights and VentureXpert. By combining these pieces of information, we are able to create three sets of indicator variables: (1) VC-backed entrepreneurs, if they were a co-founder of a firm that matched to the database of companies with VC investment; (2) Non-VC backed entrepreneurs, if they were a co-founder of a firm that did 
not match to this database; and (3) Employed at VC-backed firm, if they were employed at but not a co-founder of a firm that did match to this database.

Table 3 shows entrepreneurship outcomes after HBS. As can be seen from these descriptive statistics, the probability that an NVC participant starts a VC-backed firm, at 12 percent, is large. In the overall U.S. population, about 0.3 percent of people start a new business in any given year. ${ }^{9}$ And among all new U.S. firms, just 0.11 percent are VC-backed (Puri \& Zarutskie 2012). Moreover, while there is a difference in the probability of male participants becoming VC-backed entrepreneurs relative to female participants in our data, it is small relative to the differences documented in the broader population of U.S. startups (e.g., Gompers \& Wang 2017).

These differences between our sample and the broader population are to be expected. First, participants in the HBS NVC are much more likely to become VC-backed entrepreneurs than the population of potential entrepreneurs. Businesses founded by elite business school graduates are much more likely to be amenable to and attract VC financing than the average business started in the broader population. Second, relative to the average female entrepreneur, the sample of female participants at HBS in general, and those participating in the NVC in particular, appear to have several differentiating characteristics. They are much more likely to participate in the labor force following graduation, start new ventures in industries that tend to receive VC, and are likely less subject to the standard frictions facing typical entrepreneurs. Participation in the NVC reveals an interest in high-growth entrepreneurship, which places these women in a very selected category relative to the average woman or even the average female entrepreneur. These factors are likely to narrow the gap between the post-HBS VC-backed entrepreneurship rates across male and female participants relative to the broader population. Of course, they also mean that our results may be less externally valid. However, we believe that the elite and entrepreneurial nature of women in our sample

\footnotetext{
${ }^{9}$ See https://indicators.kauffman.org/.
} 
should act against finding an effect of exposure to networking opportunities. That is, this group of women seems especially well positioned to network effectively with VCs.

Panel B of Table 3 shows that conditional on raising VC, the companies that women in our sample build are not lower quality than those that men build. Furthermore, NVC judges score women higher than men (Table 1 Panel E). This could reflect selection into the NVC; for example, it may be that because of additional challenges to high-growth entrepreneurship that women face, only extremely high-quality women select into the NVC. This is consistent with the above point, which is that selection into the NVC should favor individuals who proactively network.

\subsection{Survey data}

As part of an effort to help the administrators of the NVC consider ways to facilitate more interaction between participants and investors, we obtained access to survey data on the networking experiences of NVC participants. The survey asked all NVC participants who were HBS alumni four Yes/No questions:

1. "After the NVC did you reach out to any judges on your panel who were VC or angel investors?"

2. "If yes, did any respond?"

3. "After the NVC did any judges on your panel who were VC or angel investors reach out to you?"

4. "If yes, did any respond?"

The following open-ended question was also included: "Optional: Please let us know any thoughts you have about the importance and ease of networking with startup investors at the NVC." 
As we outline below, we use the survey responses to provide suggestive evidence about the mechanism behind our results.

\section{Research design}

Our empirical strategy focuses on the first round of the NVC, where teams and judges are assigned to panels. NVC administrators invite individuals with a range of occupational backgrounds to judge, including investors, entrepreneurs, corporate executives, and lawyers working with startups. To facilitate allocating judges to panels, NVC administrators ask judges to fill out a self-assessment of their expertise across a number of industry sectors. This assessment is absolute rather than relative, so that a judge can claim to be an expert in more than one sector. A few days before the competition, once the pool of entrepreneurs who will actually be presenting their business plans as well as the list of judges who are available has been finalized, teams are grouped broadly along sector lines and there is some effort made to assign them to panels with judges who claimed to have expertise in their respective sectors. Administrators aim to have between five and seven judges per panel as they rightly anticipate some attrition of judges on the day of the competition. This size requirement means that some judges who are assigned to a panel may not have expertise in the sector comprising most of the ventures on the panel. ${ }^{10}$ Importantly for our analysis, judge occupations are not used to allocate judges to panels and are not even explicitly recorded by administrators. The program design therefore yields variation in the number of VCs across panels.

\footnotetext{
${ }^{10}$ Consistent with a desire to match ventures to judges with related expertise, we observe that at the sector level, there is a correlation between company and judge expertise. For example, in the startups in the IT/Software/Web category have on average 2.97 judges with related expertise, while on average non-IT startups have 2.25 judges with IT expertise on their panel, a difference that is highly significant. Matching appears strongest in health care. The only sector without such a significant correlation is Media/Education, though as Appendix Table A.1 shows, this is a small sample with just 66 participants in this sector.
} 
For our identification strategy to be valid, it must be the case that the fluctuation in the number of VCs across panels is random. In other words, matching on sector lines should not lead to systematic variation in the number of VCs across panels. Moreover, variation in the number of VCs across panels needs to be orthogonal to any characteristics of ventures that might differ along gender lines. We next demonstrate that indeed this is the case. One way in which matching along industry lines would lead to systematic variation in the number of VCs is if there were systematic differences in self-assessed sector expertise across occupations, which caused systematic differences in the number of VCs on panels by sector. The bars in Appendix Figure A.1 demonstrate that company sectors do not predict significant differences in the number of VCs. That is, VC judges are distributed fairly equally across sectors. Summary statistics about the sector composition of judges and participants are in Appendix Table A.1.

Having shown that there is no systematic variation in the number of VCs across panels by sector, we turn next to gender-specific statistics. Table 1 Panel E shows that there is no difference in the number of ventures per panel across male and female participants, nor is there systematic variation in the number of VCs or the number of sector experts that men and women are exposed to. We further show in Appendix Figure A.1 that sectors with relatively more male VC-backed entrepreneurs do not also have relatively more VCs on the panel. Finally, Appendix Table A.2 shows by sector that men are not more likely to have more VC judges in their own sector.

Together with the fact that the NVC administrators do not pay explicit attention to the occupation of judges, the results from these tests show that the program design yields fluctuation in VCs across panels that is orthogonal to participant gender. This will enable us to identify the effect of participant exposure to more relative to fewer VCs. It is important to note that our variation is not based on the gold standard of explicit random assignment, as in for example Gornall \& Strebulaev (2018). Instead, our variation stems from the NVC program design yielding random fluctuation in VCs across panels. This 
is conceptually similar to Lerner \& Malmendier (2013), who exploit the program design of HBS sections, which yields as good as random variation in the number students in a section with prior entrepreneurial backgrounds.

An important control variable that we observe is comprehensive judging data, including each judge's numeric score of the ventures on their panel. These scores are not observed by participants. Program administrators average them and then force-rank the ventures within a panel, which determines which ventures will proceed to the next round. Figure 2 uses a binscatter to show that score is correlated with subsequent VC-backed entrepreneurship. The red line provides the linear fitted values, which is the same as the coefficient on a regression of the $\mathrm{y}$-values on the $\mathrm{x}$-values. This indicates that score is a useful control for the latent quality of the venture.

Table 1 Panel E shows that female participants' teams have an average score of 3.39, where one is the lowest possible score and five is the highest. Male participants' average is a bit lower, at 3.22 (statistically different at the .05 level). Female participants have a 21 percent chance of proceeding to the semifinals, compared to a 19 percent chance for male participants, though this difference is not statistically significant. Women also have a higher chance of ultimately winning the competition in the final round. Their chance of being a finalist or runner up is nine percent, compared to seven percent for men (though again the difference is not significant). We do not use semifinals or finals data because the number of participants is far fewer, there is only one panel in each of those rounds, and there is inadequate variation in the number of $\mathrm{VC}$ judges. Our vector of competition covariates consists of the venture score in the panel, an indicator for winning the round (semifinals participation), an indicator for winning the competition (overall or runner-up), the number of ventures on the panel, the number of male judges on the panel, and the number of total judges on the panel.

Because we have (a) random variation in the number of VCs on a panel, (b) scores that are unknown to the participants, and (c) rich covariates on the individuals, we can 
estimate the differential benefit for a male entrepreneur of each extra $\mathrm{VC}$ investor on a panel. Specifically, we estimate variants of Equation 1:

$$
\begin{aligned}
& \text { VCEntrepreneur }_{i}=\alpha_{t}+\beta_{1} \text { Male }_{i} \cdot \# \text { HCsPanel } \\
&+\beta_{2} \text { Male }_{i}+\beta_{3} \# V C \text { SPanel } \\
& j
\end{aligned}
$$

Here, $t$ denotes the NVC year, $i$ denotes the HBS student participant, and $j$ denotes the competition-specific panel on which the participant pitched. The outcome of interest is an indicator for the participant becoming a VC-backed entrepreneur after HBS. Our primary approach uses year fixed effects $\left(\alpha_{t}\right)$, but we also show the results with panel fixed effects

$\left(\alpha_{j}\right)$, which absorb the year. The coefficient of interest is $\beta_{1}$ on the interaction between the participant being male and the number of VCs on the panel. We cluster standard errors at the panel level, and the results are also robust to clustering at the venture level.

\section{Results}

This section first presents the main results, both visually and from the regression model in Equation 1 (Section 4.1). Robustness tests are discussed in Section 4.2.

\subsection{Main results}

Before showing regression evidence, we begin by presenting raw averages consistent with our main result. Table 2 Panel B shows the share of participants who subsequently become VC-backed entrepreneurs by gender and the panel's number of VC judges. For women, the rate of VC-backed entrepreneurship exhibits no relationship to the number of $\mathrm{VC}$ judges. However, for men, there is a strong association. Men have a nine percent chance of becoming VC-backed entrepreneurs with two or fewer VCs on the panel, a 12 percent chance with three to four VCs, and an 18 percent chance with five or more VCs 
on the panel. This relationship is demonstrated graphically in Figure 1 using binscatters, in which each number of VCs on the panel is a bin. The dots indicate the average chance that an individual in the bin founds a VC-backed startup (that is, it is the mean of all observations in the bin). The left figure shows that venture backing is monotonically increasing in the number of VCs on the panel among men. In striking contrast, the right figure shows that there is a much weaker relationship for women, if any.

We move to estimates of Equation 1 in Table 4. Our main specification in column 1 finds that each additional VC on the panel makes male participants 3.1 percentage points more likely to become a VC-backed entrepreneur, relative to female participants. This is large in economic magnitude; it is about 25 percent of the mean rate of 12 percent. Moving across columns in Table 4, it is comforting that the effect without any controls is close in magnitude to the effect with the rich person and competition controls (17 personlevel indicator variables and five panel-level competition controls). Table 4 column 2 omits person controls, and column 3 omits competition controls as well. We include panel fixed effects $\left(\alpha_{j}\right)$ in column 4 . This yields a slightly higher coefficient of interest, at 4.4 percentage points. Columns 5-6 show that the results are robust to including sector and sector by gender fixed effects.

In column 7 , we restrict $\mathrm{VC}$ backing to the first venture that the participant founded after the competition date. In other words, if a participant first founded a venture without VC investment after the NVC and then later founded a VC-backed venture, the dependent variable in this specification is coded as zero. The coefficient of .026 is about 80 percent of the main effect, consistent with the first venture post-HBS driving the results.

The final column of Table 4 shows that we find similar results at the venture level. Here, the dependent variable is the chance that the venture specifically, rather than the individual, subsequently receives VC backing. We use a categorical independent variable that takes one of three values depending on whether the team is all male, mixed, or all 
female (omitted). ${ }^{11}$ Note that many ventures have only one HBS team member participating, so the sample size decreases by only about one third. The results indicate that all-male teams benefit from more VCs on the panel. There is no economic or statistical difference between mixed teams and all-female teams.

We separately consider male and female VC judges. As noted in Section 2.1, there are few female VCs, and thus little variation across panels. We therefore do not expect to identify a robust different effect for women judges. Appendix Table A.3 column 1 shows that as expected, our effect is only significantly different from zero for male VCs. The coefficient for female VCs is not significantly different from zero, but it is large in magnitude. Therefore, we cannot rule out that the effect of exposure to VC judges benefits men regardless of the gender of the judge. However, existing research, such as Ewens \& Townsend (2019), has found evidence of gender-based homophily in early stage investing.

The results are largely driven by early-stage VCs. We manually researched whether the VCs' firms primarily do early, late, or not specialized investing. Where available, we relied on Crunchbase's categorization. Otherwise, we used Pitchbook deal types and firm websites. We were able to assign a stage to 126 unique VC firms. Of these, 40 are early specialists, typically focusing on Series A rounds (not the seed or angel deals that are more typically a startup's first outside financing). Of the remainder, 22 are late specialists, and 64 do not specialize. In Appendix Table A.4, we interact "Male" with the number of VCs of a particular stage. The coefficient on the interaction between "Male" and the number of early stage VCs is 0.055 , larger than our main estimate (column 1). The other two coefficients are insignificant, but the one for "Late" is -.011 while the one for "Not Specialized" is .023, suggesting possible monotonicity in early stage deal making. The means for Early, Late, and Not Specialized are 0.48, 0.26, and 1.03, respectively. While our results are not driven by the VCs themselves investing in the very early stage

\footnotetext{
${ }^{11}$ There are 221 all female teams, 182 mixed teams, and 561 all male teams, so the average of this variable is 1.35 .
} 
participating ventures, it is not surprising that the VCs with the most relevant networks are those that specialize in early stage deals.

We explore whether the number of VCs on the panel leads to different startup outcomes by gender conditional on the startup receiving VC funding in Appendix Table A.5. A caveat to this analysis is that since we are conditioning on those who started VC-backed ventures, the sample is quite small. Columns 1-3 consider the amount of VC financing within two years of the competition. In column 3, we use an indicator for financing above the 90th percentile. The coefficient suggests that an additional VC increases the chances of very high funding for men relative to women by about 14 percentage points. Columns 7-8 find no significant effects on real outcomes in the forms of acquisition or employment. These results, while imprecisely measured, suggest that the networking friction we observe acts on the extensive margin of becoming a VC-backed entrepreneur. Conditional on raising $\mathrm{VC}$, women appear to have established the necessary networks to succeed.

In sum, the results indicate that exposure to VCs in particular is more useful to nascent male entrepreneurs than to their female counterparts. Beyond VC judges' expertise in evaluating startups, networking value is no doubt one reason why new venture competitions (including HBS) try to include as many of them in their judge pool as possible. We demonstrate that this networking value accrues disproportionately to male founders.

While our research design offers strong identification, the external validity of our results depends on the nature of selection into HBS and into the NVC. We believe that our findings may generalize to the broader population. As we noted in the introduction, our goal is not to explain the relative importance of various channels that might lead to the gender gap in entrepreneurship, but rather to shed light on the particular channel of networking frictions. We believe the highly motivated, relatively well-networked women in our sample likely face fewer of these frictions than women in the broader population. 
Therefore, the gender-based networking frictions we identify are likely present in highgrowth entrepreneurship more generally. That said, the selected sample of HBS NVC participants is a potential limitation of our study.

\subsection{Robustness tests}

Placebo tests offer compelling evidence that our effect is not spurious. In Table 5 columns 1 and 2, we use the alternative outcome variables of non- $\mathrm{VC}$ backed entrepreneurship and employment at a VC-backed company. In both cases, there is no effect of the interaction


affect VC-backed entrepreneurship. All of the judges are highly successful individuals with some connection to entrepreneurship (e.g., lawyers for startups, executives running corporate venture programs), so it is possible that our effect reflects useful connections based on other characteristics that may be correlated with being a VC. In column 3, we interact Male $_{i}$ with the number of male judges on the panel in case gender homophily is the source of our effect. While the coefficient is positive (2.1 percentage points), it is imprecisely estimated and not statistically significant. To ensure that sector matching does not drive the result, column 4 uses the number of judges on the panel who are in the venture's sector. It finds a small and insignificant, albeit positive, effect. We consider the number of all judges that are not VCs in column 5, and more specifically the number

of entrepreneurs and corporate executive judges in columns 6 and 7 , respectively. In all cases, the coefficient is small, negative, and insignificant.

A different type of concern arises from the possibility that men have higher quality ventures, and VCs more accurately assess quality. We can use the private scoring data to speak to this concern. First, it is important to demonstrate that the scores contain useful information, as Howell (2019) finds in a larger sample of competitions. Indeed, on average scores are strongly correlated with VC-backed entrepreneurship, which is shown in Table 
6 column 1 (note that winning is included as a control). This relationship is robust to including the Male $_{i}$ indicator in column 2. We then shift to predicting the score using gender and the number of VCs. Column 3 shows that men score slightly lower than women do on average, consistent with the summary statistics reported above. This correlation persists when \#VCsPanel ${ }_{j}$ and the interaction Male $_{i} \cdot \# V C s$ Panel $_{j}$ are included as controls. There is no significant effect of the interaction on scores. In unreported results, we also find that VC scores are no different than other judge scores. In sum, our results do not appear to be driven by VC judges perceiving women-led ventures to be lower quality.

A related concern is that our main finding reflects some characteristic correlated with gender. In Appendix Table A.6 Panel 1 we interact \#VCsPanel $j$ with a wide array of relevant previous job experiences: previous VC-backed entrepreneurship (column 1), previous non-VC-backed entrepreneurship (column 2), previous employment at a VCbacked company (column 3), previous employment at a VC firm (column 4), previous employment in management consulting (column 5), and previous employment in financial services (column 6). In no case do we observe an effect of the interaction between the job experience and the number of VCs on the panel. In Panel 2, we consider six additional binary participant characteristics: undergraduate degree from an Ivy + college (column 1), HBS honors (column 2), computer science major (column 3), engineering major (column 4), econ/business major (column 5), and winning the NVC round (column 6). We again find no effects, with one exception. The interaction is significant for participants whose college major was economics/business. This major is uncorrelated with gender.

In Appendix Table A.7 we split the sample by time period and number of ventures on the panel to test whether a part of our sample is responsible for the effect (though note we control for these factors in the main model). The results suggest a somewhat stronger effect in the later period, though the two coefficients are not significantly different. However, to the extent this difference may be substantive, it could indicate a higher value of networking resources in early stage entrepreneurship in more recent years, when the 
explosion of entrepreneurial activity perhaps made it harder to screen ventures.

Finally, we considered whether there are effects on other types of entrepreneurial finance. We grouped non-VC investment into two categories: "Angel" and "Other Early." The former includes angel and seed deals. The latter includes grants, incubators, accelerators, business plan competitions, and crowdfunding. We identified 56 NVC participant ventures that raised Angel and 21 that raised Other Early, together corresponding to $129 \mathrm{HBS}$ student participants. In unreported analysis, we find no significant effects on Angel or Other Early at either the venture or individual level. However, at the individual level, the effect on Angel is .022 with a p-value of .105, suggesting that a weaker version of the main finding may exist for angel and seed investment. These results support the argument that women face the biggest networking barriers in raising formal VC.

\section{Survey results}

Our main results show that exposure to more VCs benefits male NVC participants more than female participants. This is consistent with women having a more difficult time taking advantage of networking opportunities with VCs. If there is a greater friction in any given interaction between VCs and female participants, the overall impact will be more consequential in panels with more VCs. To probe this channel further and determine the degree to which this friction might be due to the participants or the investors, we turn to the survey evidence. The first step in examining the survey evidence is to test for response bias in the variables of interest. Table 7 columns 1 and 2 show that men were no more likely than women to respond to the survey. Further, there is no association between responsiveness and either the number of VCs on the panel or VC-backed entrepreneurship (column 2).

We then turn to analyzing the results within the sample of 172 respondents. Men 
were much more likely to report having reached out to a VC judge after the competition. Columns 3 and 4 show that men were 16-21 percentage points more likely to reach out, depending on whether we include person and competition controls. Among survey respondents, 26 percent reached out. Therefore, our preferred specification in column 4 implies that men were 81 percent more likely than women to reach out to VCs. However, men were not significantly more likely than women to report a VC judge reaching out to them after the competition (column 5). Among participants who reached out to a VC judge, we observe a positive but insignificant coefficient on interaction Male $_{i} \cdot \# V C s$ Panel $_{j}$ (column 6). Conditional on reaching out to a judge, male and female participants report the judge responding in equal numbers (column 7). It is important to emphasize that the sample is very small in columns 6 and 7 , so the results should be interpreted with caution.

Despite its limitations, the survey results offer suggestive evidence that our main findings reflect women being less likely to initiate networking with VCs. This is corroborated by some of the responses to an open-ended question in the survey about the importance or ease of networking at the NVC. For example, one woman wrote the following: "I think [networking at the NVC] would have been amazing. I didn't think it was appropriate at the time/or was perhaps a bit shy to reach out. In general, I think encouraging future entrepreneurs to be very comfortable scheduling meetings/coffees/chats with the community would be hugely beneficial."

\section{Conclusion}

This paper helps to characterize one friction that might lead to the well-documented discrepancy between the rates at which men and women found VC-backed startups: barriers to networking between entrepreneurs and investors. There are of course many (not mutually exclusive) potential reasons why women might not receive $\mathrm{VC}$ in the same 
proportion as their share of the population. Our goal in this paper is not to investigate the relative importance of different drivers, but rather to study whether networking frictions could be a source of differential access that might play an important role in the variation we see in observed rates of $\mathrm{VC}$ finance. We expect that networking-related information frictions are likely to be particularly important in VC, given the large amount of asymmetric information and the high weight that VCs appear to place on face-to-face connections and trusted referrals as deal sourcing methods. This reliance on networks may privilege those who are more connected or those who are most comfortable forming connections with investors.

Exploiting random variation in the number of VCs across judging panels at the Harvard Business School New Venture Competition (HBS NVC), we find that additional VCs on a panel increase the likelihood of a male participant starting a VC-backed venture after graduation but have no meaningful impact among female participants. That is, women assigned to panels with many VCs benefit less from this 'lucky draw' than men who were assigned to these panels. Our survey evidence points to this difference being driven by the fact that women are less likely to proactively reach out to VCs after the NVC.

There are numerous reasons why women might be less likely to proactively network than men. Men and women may have different beliefs about appropriate networking norms. There may also be homophily in networking, where individuals might feel more comfortable networking with others of the same gender. Since most VCs are men, this would lead to lower rates of networking with VCs among women. Furthermore, women may not reach out if they anticipate discrimination or harassment on the part of investors. We cannot distinguish between these hypotheses. Nevertheless, the fact that the survey points to the entrepreneurs rather than the VCs driving the networking discrepancy is important. There is evidence that women are less proactive or hold themselves to a higher standard than men in other settings as well. For example, Chari \& Goldsmith-Pinkham (2017) find that gender differences in submission rates of papers to the National Bureau of 
Economic Research's elite Summer Institute conference can explain the substantial gender gap among accepted authors. As a second example, Kolev, Fuentes-Medel \& Murray (2019) find that the reason women score lower in blinded grant application evaluations is because they tend to use more narrow words, despite having better scientific output conditional on funding. ${ }^{12}$

More generally, since the individuals behind ideas are intricately tied to the ideas themselves at a venture's earliest stages, and the distribution of good ideas is not perfectly correlated to the distribution of good access to $\mathrm{VC}$, our results suggest that promising ideas may go unfunded because of systematic variations in $\mathrm{VC}$ access rather than because of the inherent quality of the idea. This is likely to be particularly salient when such access is mediated by the extent to which entrepreneurs proactively reach out to, and network with investors. Our results suggest that future research studying which interventions most effectively reduce networking-related frictions will be extremely valuable.

\footnotetext{
${ }^{12}$ Note that women are not universally less proactive in ways that are detrimental to their outcomes; Exley, Niederle \& Vesterlund (2019) isolate the decision to negotiate in a laboratory experiment and find that while women tend to negotiate less, this is not suboptimal as negotiating more leads to losses.
} 


\section{References}

Barber, B. M. \& Odean, T. (2001), 'Boys will be boys: Gender, overconfidence, and common stock investment', The quarterly journal of economics 116(1), 261-292.

Becker-Blease, J. R. \& Sohl, J. E. (2007), 'Do women-owned businesses have equal access to angel capital?', Journal of Business Venturing 22, 503-521.

Bell, A., Chetty, R., Jaravel, X., Petkova, N. \& Van Reenen, J. (2018), 'Who becomes an inventor in america? the importance of exposure to innovation', The Quarterly Journal of Economics 134(2), 647-713.

Bertrand, M. (2013), 'Career, family, and the well-being of college-educated women', The American Economic Review 103(3), 244-250.

Bertrand, M., Goldin, C. \& Katz, L. F. (2010), 'Dynamics of the gender gap for young professionals in the financial and corporate sectors', American Economic Journal: Applied Economics 2(3), 228-255.

Bertrand, M., Kamenica, E. \& Pan, J. (2015), 'Gender identity and relative income within households', The Quarterly Journal of Economics 130(2), 571-614.

Brooks, A. W., Huang, L., Kearney, S. W. \& Murray, F. E. (2014), 'Investors prefer entrepreneurial ventures pitched by attractive men', Proceedings of the National Academy of Sciences 111(12), 4427-4431.

Castillo, M., Petrie, R., Torero, M. \& Vesterlund, L. (2013), 'Gender differences in bargaining outcomes: A field experiment on discrimination', Journal of Public Economics 99, 35-48.

Chari, A. \& Goldsmith-Pinkham, P. (2017), Gender representation in economics across topics and time: Evidence from the nber summer institute, Technical report, National Bureau of Economic Research.

Cohen, L., Frazzini, A. \& Malloy, C. (2008), 'The small world of investing: Board connections and mutual fund returns', Journal of Political Economy 116(5), 951-979.

Cook, C., Diamond, R., Hall, J., List, J. A. \& Oyer, P. (2018), The gender earnings gap in the gig economy: Evidence from over a million rideshare drivers, Technical report, National Bureau of Economic Research.

Ewens, M. \& Townsend, R. R. (2019), 'Are early stage investors biased against women?', Journal of Financial Economics .

Exley, C. L., Niederle, M. \& Vesterlund, L. (2019), Knowing when to ask: The cost of leaning-in, Technical report, Journal of Political Economy.

Fang, L. H. \& Huang, S. (2017), 'Gender and connections among wall street analysts', The Review of Financial Studies 30(9), 3305-3335. 
Goldin, C., Kerr, S. P., Olivetti, C. \& Barth, E. (2017), 'The expanding gender earnings gap: evidence from the lehd-2000 census', American Economic Review 107(5), 110-14.

Gompers, P. A. \& Wang, S. Q. (2017), 'Diversity in innovation', NBER Working Paper (23082).

Gornall, W. \& Strebulaev, I. A. (2015), 'The economic impact of venture capital: Evidence from public companies', Working Paper.

Gornall, W. \& Strebulaev, I. A. (2018), 'Gender, race, and entrepreneurship: A randomized field experiment on venture capitalists and angels'. Working Paper.

Hengel, E. (2017), 'Publishing while female. are women held to higher standards? evidence from peer review.'.

Hochberg, Y. V., Ljungqvist, A. \& Lu, Y. (2007), 'Whom you know matters: Venture capital networks and investment performance', The Journal of Finance 62(1), 251-301.

Howell, S. (2019), 'Reducing information frictions in venture capital: Evidence from new venture competitions'. NBER Working Paper 23874.

Kaplan, S. N. \& Lerner, J. (2010), 'It ain't broke: The past, present, and future of venture capital', Journal of Applied Corporate Finance 22(2), 36-47.

Kerr, W. R. \& Mandorff, M. (2015), Social networks, ethnicity, and entrepreneurship, Technical report, National Bureau of Economic Research.

Kerr, W. R., Nanda, R. \& Rhodes-Kropf, M. (2014), 'Entrepreneurship as experimentation', The Journal of Economic Perspectives 28(3), 25-48.

Kolev, J., Fuentes-Medel, Y. \& Murray, F. (2019), 'Is blinded review enough? how gendered outcomes arise even under anonymous evaluation'.

Lerner, J. \& Malmendier, U. (2013), 'With a little help from my (random) friends: Success and failure in post-business school entrepreneurship', Review of Financial Studies 26(10), 24112452.

Levine, R. \& Rubinstein, Y. (2017), 'Smart and illicit: who becomes an entrepreneur and do they earn more?', The Quarterly Journal of Economics 132(2), 963-1018.

Niederle, M. \& Vesterlund, L. (2007), 'Do women shy away from competition? do men compete too much?', The Quarterly Journal of Economics 122(3), 1067-1101.

Pew (2013), 'On pay gap millennial women near parity for now'. Pew Research Center Report.

Pew (2015), 'Women and leadership public says women are equally qualified, but barriers persist' Pew Research Center Report.

Puri, M. \& Zarutskie, R. (2012), 'On the life cycle dynamics of venture-capital-and non-venturecapital-financed firms', The Journal of Finance 67(6), 2247-2293.

Reuben, E., Sapienza, P. \& Zingales, L. (2014), 'How stereotypes impair women's careers in science', Proceedings of the National Academy of Sciences 111(12), 4403-4408. 
Sapienza, P., Zingales, L. \& Maestripieri, D. (2009), 'Gender differences in financial risk aversion and career choices are affected by testosterone', Proceedings of the National Academy of Sciences 106(36), 15268-15273.

Scott, E. L. \& Shu, P. (2017), 'Gender gap in high-growth ventures: Evidence from a university venture mentoring program', American Economic Review P\&P 107(5).

Stuart, T. E. \& Sorenson, O. (2005), Social networks and entrepreneurship, in 'Handbook of entrepreneurship research', Springer, pp. 233-252. 
Figure 1: Relationship between Number of VCs on Panel and VC-backed Entrepreneurship
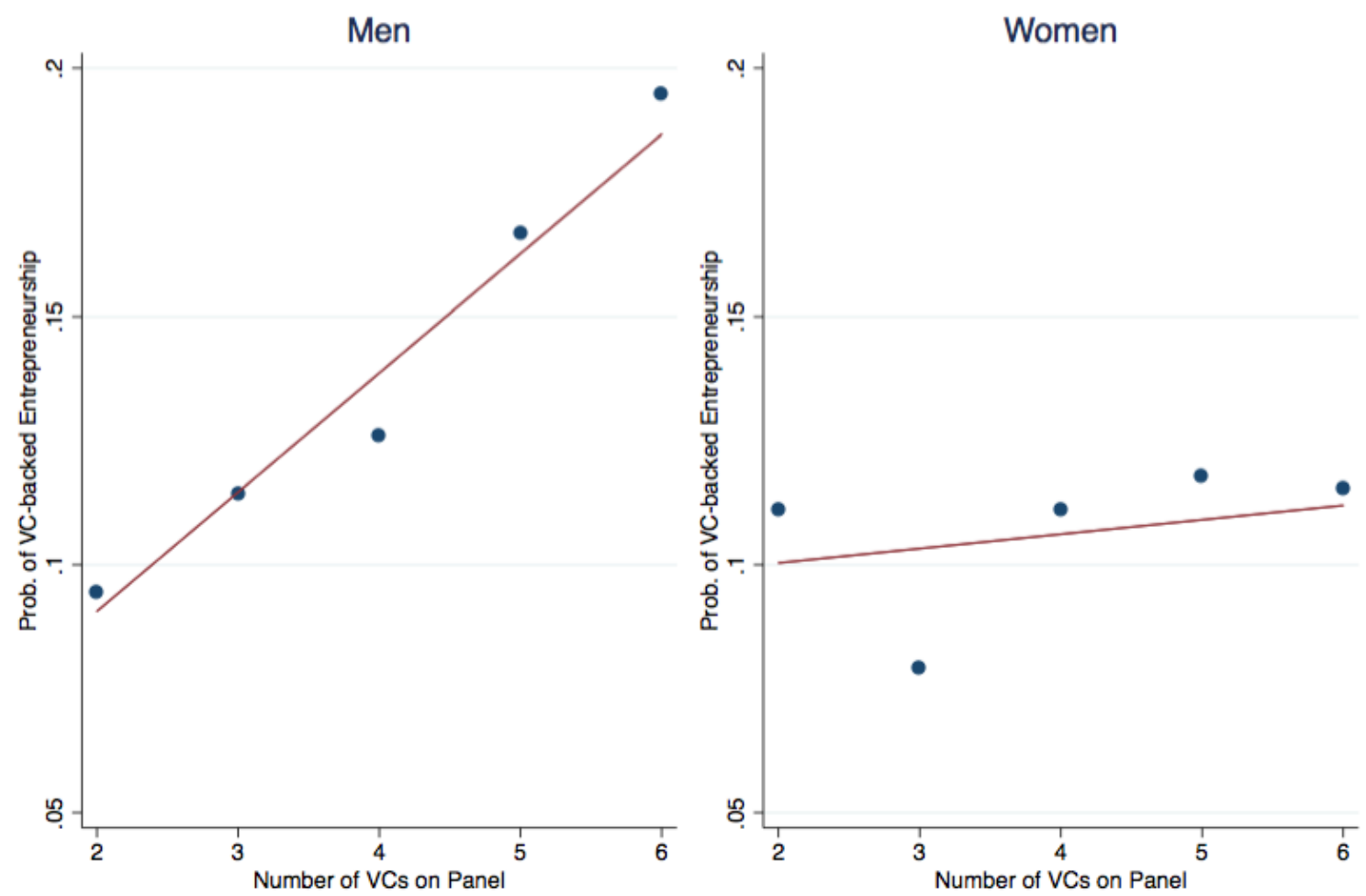

Note: These figures show binscatters of the relationship between the number of VCs on the judging panel for a participant, and the probability of VC-backed entrepreneurship for individuals on the venture's team. The left figure restricts the sample to men, and the right figure to women. 0-2 and 6-8 VCs are collapsed into a single category. Together, the figures include all 964 individuals in the HBS NVC. 
Figure 2: Relationship between Venture Score in Panel and VC-backed Entrepreneurship

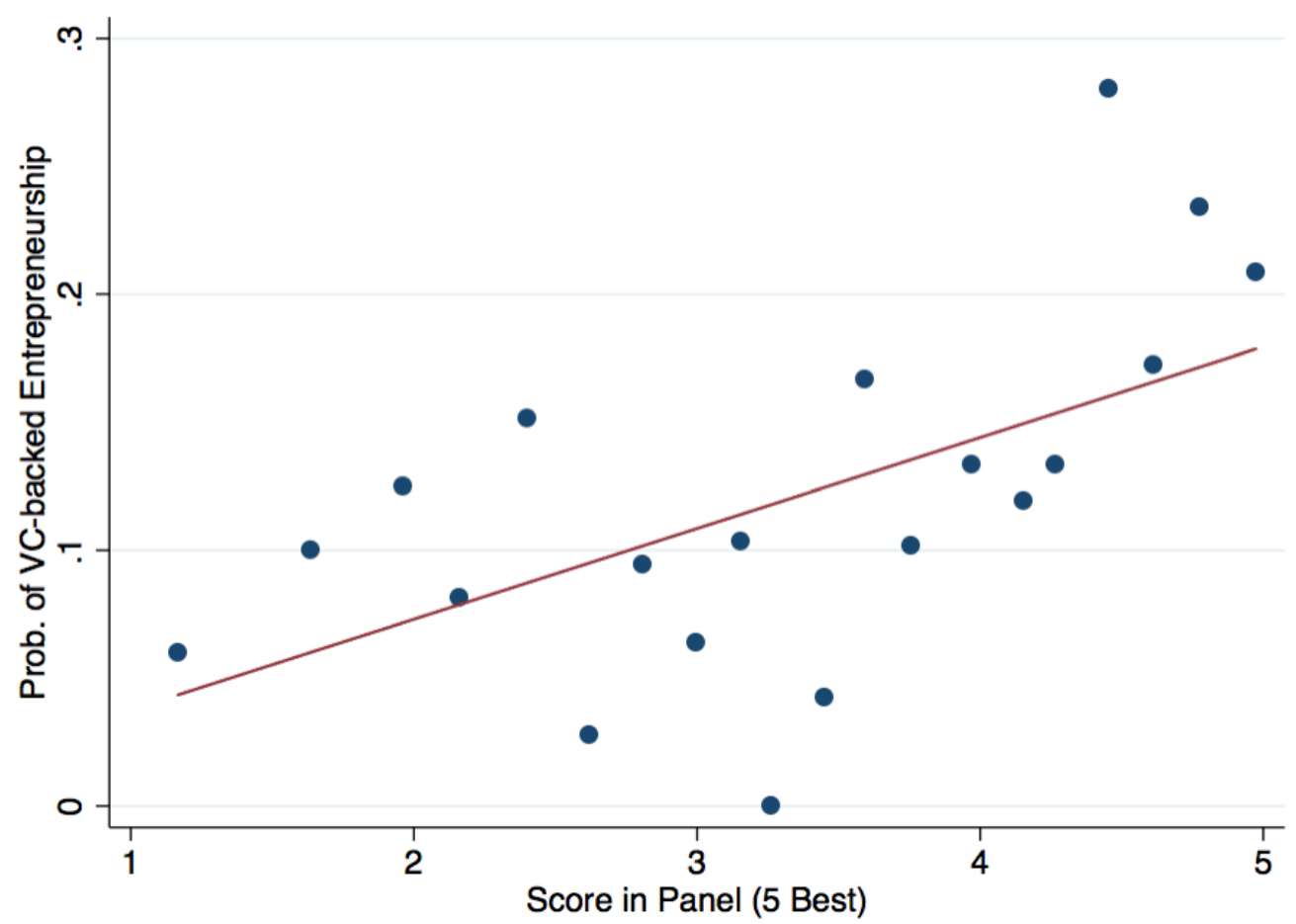

Note: This figure shows a binscatter of the relationship between the score that a venture receives, and probabilities of VC-backed entrepreneurship for individuals on the venture's team. All 964 individuals in the HBS NVC are included. A score of 5 is the best, and 1 is the worst. 
Table 1: Characteristics of participants

\begin{tabular}{|c|c|c|c|c|}
\hline \multicolumn{5}{|c|}{ A. Count of individuals } \\
\hline & All & Female & Male & Fraction female \\
\hline Number of individuals & 964 & 307 & 657 & 0.32 \\
\hline \multicolumn{5}{|c|}{ B. Team size (Means) } \\
\hline & All & Female & Male & $\begin{array}{c}\text { P-value } \\
\text { (male - female) }\end{array}$ \\
\hline Mean team size including non-HBS participants & 2.53 & 2.55 & 2.52 & 0.56 \\
\hline Mean team size, HBS participants only & 1.79 & 1.83 & 1.77 & 0.24 \\
\hline \multicolumn{5}{|c|}{ C. Professional background before HBS (Means) } \\
\hline & All & Female & Male & $\begin{array}{c}\text { P-value } \\
\text { (male - female) }\end{array}$ \\
\hline Entrepreneurship & 0.26 & 0.23 & 0.27 & 0.17 \\
\hline VC-backed company employment & 0.45 & 0.48 & 0.44 & 0.17 \\
\hline VC firm employment & 0.04 & 0.04 & 0.04 & 0.85 \\
\hline Finance employment & 0.27 & 0.32 & 0.25 & 0.01 \\
\hline Consulting employment & 0.29 & 0.31 & 0.28 & 0.34 \\
\hline \multicolumn{5}{|c|}{ D. Stated relevant interests and activities at HBS (Means) } \\
\hline & All & Female & Male & $\begin{array}{c}\text { P-value } \\
\text { (male - female) }\end{array}$ \\
\hline Interest in entrepreneurship & 0.18 & 0.19 & 0.17 & 0.48 \\
\hline Interest in management & 0.07 & 0.06 & 0.08 & 0.29 \\
\hline Interest in consulting & 0.12 & 0.19 & 0.09 & 0.00 \\
\hline Interest in finance & 0.28 & 0.24 & 0.29 & 0.08 \\
\hline HBS Entrepreneurship club member & 0.08 & 0.08 & 0.08 & 0.91 \\
\hline
\end{tabular}

Note: These panels contain statistics on the 964 HBS participants in the HBS NVC from 2000 to 2015. Team size is a venture-level variable, but is summarized at the individual level. Team size including non-HBS participants reflects additional individuals who are not included in estimation. Indicators for professional background (e.g. Finance employment) reflect whether the individual had any instance of that experience; participants may have had multiple jobs before HBS. P-value is two-tailed. 


\section{E. Panel composition and NVC outcomes (Means)}

\begin{tabular}{|c|c|c|c|c|}
\hline & All & Female & Male & $\begin{array}{c}\text { P-value } \\
\text { (male - female) }\end{array}$ \\
\hline Total number of judges on panel & 6.00 & 5.93 & 6.01 & 0.47 \\
\hline Number of VC judges on panel & 3.29 & 3.21 & 3.33 & 0.28 \\
\hline Number of male VC judges on panel & 2.78 & 2.71 & 2.81 & 0.32 \\
\hline Number of judges in own sector on panel & 2.44 & 2.33 & 2.49 & 0.17 \\
\hline Match to judges in own sector on panel & 0.80 & 0.84 & 0.79 & 0.09 \\
\hline Match to VC judges in own sector on panel & 0.72 & 0.74 & 0.71 & 0.27 \\
\hline Number of entrepreneur judges on panel & 0.85 & 0.87 & 0.84 & 0.61 \\
\hline Number of corporate executive judges on panel & 0.97 & 0.93 & 0.99 & 0.32 \\
\hline Number of ventures on the panel & 4.82 & 4.80 & 4.83 & 0.69 \\
\hline Score in panel ( 1 worst, 5 best) & 3.27 & 3.39 & 3.22 & 0.01 \\
\hline First round winner & 0.20 & 0.21 & 0.19 & 0.40 \\
\hline Finals winner or runner-up & 0.07 & 0.09 & 0.07 & 0.25 \\
\hline
\end{tabular}

Note: This panel contains statistics on the 964 HBS participants in the HBS NVC from 2000 to 2015.

The unit of observation is the individual participant, but the first six variables are at the panel level (in the first round of the competition, which is the focus of our study, ventures pitch and are scored within panels). We observe a total of 180 panels across all years. As an example of interpretation, the first two rows indicate that female participants are assigned to panels that have on average 5.93 judges, of which 3.21 are venture capitalists (VCs). The last three variables are at the team (i.e. venture) level, though again the unit of observation is the individual. For example, female participants' teams average score is 3.39 , and they have a 0.21 chance of winning the first round. P-value is two-tailed. 
Table 2: Characteristics of NVC Judging Panels by Number of VC Judges on Panel A. Number of judges and participants (Means)

\begin{tabular}{lccc} 
& $\leq 2 \mathrm{VCs}$ & $3-4 \mathrm{VCs}$ & $\geq 5 \mathrm{VCs}$ \\
Number of judges on panel & 5.8 & 5.9 & 6.5 \\
Number of ventures in panel & 3.6 & 3.6 & 3.6 \\
Number of participants & 5.2 & 5.4 & 5.5 \\
\hline
\end{tabular}

B. Share of panel participants with post-HBS VC-backed entrepreneurship

\begin{tabular}{lccc} 
& $\leq 2 \mathrm{VCs}$ & $3-4 \mathrm{VCs}$ & $\geq 5 \mathrm{VCs}$ \\
Share of males & 0.09 & 0.12 & 0.18 \\
Share of females & 0.11 & 0.09 & 0.12 \\
\hline \hline
\end{tabular}

Note: This table reports descriptive statistics at the panel level, for the 180 judging panels in the HBS NVC from 2000 to 2015. We separately consider panels by the number of VCs. There are 62 panels with $\leq 2 \mathrm{VCs}, 81$ panels with $3-4 \mathrm{VCs}$, and 37 panels with at least 5 VCs. 


\section{A. Individual entrepreneurship-related outcomes (Means)}

\begin{tabular}{|c|c|c|c|c|}
\hline & All & Female & Male & $\begin{array}{c}\text { P-value } \\
\text { (male - female) }\end{array}$ \\
\hline VC-backed entrepreneurship & 0.12 & 0.10 & 0.13 & 0.36 \\
\hline Non-VC-backed entrepreneurship & 0.20 & 0.17 & 0.21 & 0.23 \\
\hline VC-backed startup employment & 0.48 & 0.52 & 0.46 & 0.07 \\
\hline
\end{tabular}

B. Venture outcomes conditional on VC-backed entrepreneurship

\begin{tabular}{lccccccc} 
& \multicolumn{2}{c}{ All } & \multicolumn{2}{c}{ Female } & \multicolumn{2}{c}{ Male } & $\begin{array}{c}\text { P-value } \\
\text { (male - female) }\end{array}$ \\
& & & & & & & \\
& N & Mean & N & Mean & N & Mean & \\
Judge or judge's firm invested & 114 & 0.02 & 32 & 0.00 & 82 & 0.02 & 0.38 \\
Funding within 2 yrs of NVC (mill \$) & 73 & 45 & 21 & 37 & 52 & 48 & 0.84 \\
Funding within 5 yrs of NVC (mill \$) & 73 & 128 & 21 & 231 & 52 & 87 & 0.07 \\
$>10$ employees as of March, 2018 & 114 & 0.64 & 32 & 0.69 & 82 & 0.62 & 0.52 \\
Venture acquired & 114 & 0.22 & 32 & 0.16 & 82 & 0.24 & 0.31 \\
\hline
\end{tabular}

Note: This table reports descriptive statistics on HBS participants in the HBS NVC from 2000 to2015. The number of observations is 964 (all participants) in Panel A. Panel B restricts the sample to the 114 ventures with VC funding founded by participants. Further, funding statistics are limited to the 73 ventures for which we have funding data. Note that indicators for professional outcomes (e.g. VC-backed startup employment) reflect whether the individual had any instance of the outcome; participants may have multiple jobs post-HBS. P-value is two-tailed. 
Table 4: Effect of VC Judges on Subsequent VC-backed Entrepreneurship by Gender

Dependent variable: VC-backed Entrepreneurship

\begin{tabular}{|c|c|c|c|c|c|c|c|c|}
\hline & (1) & $(2)$ & $(3)$ & $(4)$ & (5) & $(6)$ & $(7)$ & (8) \\
\hline \multirow[t]{2}{*}{ Male·\# VCs on Panel } & $.031^{* *}$ & $.029^{* *}$ & $.027^{*}$ & $.044^{* *}$ & $.035^{* *}$ & $.029^{*}$ & $.026^{*}$ & $.028^{* *}$ \\
\hline & $(.014)$ & $(.014)$ & $(.014)$ & $(.019)$ & $(.016)$ & $(.015)$ & $(.014)$ & $(.013)$ \\
\hline \multirow[t]{2}{*}{ Male } & -.077 & -.067 & -.07 & -.112 & -.08 & -.087 & -.060 & $-.097^{*}$ \\
\hline & $(.049)$ & $(.051)$ & $(.051)$ & $(.071)$ & $(.062)$ & $(.064)$ & $(.048)$ & $(.051)$ \\
\hline \multirow[t]{2}{*}{ \# VCs on Panel } & -.014 & -.009 & -.006 & & -.011 & -.005 & -.016 & $-.020^{*}$ \\
\hline & $(.012)$ & $(.012)$ & $(.012)$ & & $(.012)$ & $(.012)$ & $(.011)$ & $(.012)$ \\
\hline \multirow[t]{2}{*}{ Mixed·\# VCs on Panel } & & & & & & & & .005 \\
\hline & & & & & & & & $(.019)$ \\
\hline \multirow[t]{2}{*}{ Mixed } & & & & & & & & -.032 \\
\hline & & & & & & & & $(.084)$ \\
\hline Person Controls & $\mathrm{Y}$ & & & $\mathrm{Y}$ & $\mathrm{Y}$ & & $\mathrm{Y}$ & \\
\hline Competition Controls & $\mathrm{Y}$ & $\mathrm{Y}$ & & $\mathrm{Y}$ & $\mathrm{Y}$ & & $\mathrm{Y}$ & $\mathrm{Y}$ \\
\hline Year (cohort) FE & $\mathrm{Y}$ & $\mathrm{Y}$ & $\mathrm{Y}$ & & $\mathrm{Y}$ & Y & $\mathrm{Y}$ & \\
\hline Panel FE & & & & $\mathrm{Y}$ & & & & \\
\hline Male-Sector FE & & & & & $\mathrm{Y}$ & Y & & \\
\hline Sector FE & & & & & $\mathrm{Y}$ & $\mathrm{Y}$ & & \\
\hline $\mathrm{N}$ & 964 & 964 & 964 & 964 & 879 & 879 & 964 & 647 \\
\hline$R^{2}$ & .100 & .071 & .051 & .260 & .11 & .068 & .100 & .036 \\
\hline
\end{tabular}

Note: This table shows the effect of the number of venture capitalists (VCs) on the probability that a male participant in the HBS NVC subsequently founds a VC-backed venture, relative to female participants. In column 7, only VC financing for the first venture founded after the NVC is included in the dependent variable. In column 8 , we conduct the analysis at the venture level. We use a categorical variable that takes one of three values for whether the team is: all female, mixed, or male. All female is omitted. Person controls consist of the following indicator variables: Interest in entrepreneurship, interest in finance, interest in management, entrepreneurship or VC clubs membership at HBS, previous VC-backed entrepreneurship experience, previous work for a VC-backed startup, previous work for a VC firm, previous non-VC backed entrepreneurship, honors at HBS, US citizen, computer science college major, engineering college major, economics/business/management college major, and college degree from an Ivy + university. Competition controls consist of the following: The venture score in the panel, indicator for winning the competition (overall or runner-up), the number of ventures on the panel, the number of male judges on the panel, and the number of total judges on the panel. There are six sectors: IT/Software/Web, Consumer Goods, Media/Education, Tough Tech (Tangible High Tech), Financial/Real Estate, and Health. There are fewer observations in columns 5-6 because we do not observe sector for all ventures. Standard errors are clustered by panel. $*, * *$, and $* * *$ denote significance at the 10 percent, 5 percent, and 1 percent levels. 
Table 5: Placebo Tests for Effect of VC Judges on VC-backed Entrepreneurship

\begin{tabular}{|c|c|c|c|c|c|c|c|}
\hline \multirow[t]{2}{*}{ Dependent variable: } & \multirow{2}{*}{$\begin{array}{c}\text { Non-VC- } \\
\text { backed } \\
\text { Entrep. } \\
\\
(1) \\
\end{array}$} & \multirow{2}{*}{$\begin{array}{c}\text { VC- } \\
\text { backed } \\
\text { Co Emp } \\
(2) \\
\end{array}$} & \multicolumn{5}{|c|}{ VC-backed Entrepreneurship } \\
\hline & & & $(3)$ & $(4)$ & $(5)$ & $(6)$ & $(7)$ \\
\hline Male·\# VCs on Panel & $\begin{array}{c}.007 \\
(.016)\end{array}$ & $\begin{array}{c}.006 \\
(.022)\end{array}$ & & & & & \\
\hline Male·\# Males on Panel & & & $\begin{array}{c}.021 \\
(.015)\end{array}$ & & & & \\
\hline Male·\# Own Sector on Panel & & & & $\begin{array}{c}.012 \\
(.013)\end{array}$ & & & \\
\hline Male.\# non-VCs on Panel & & & & & $\begin{array}{l}-.002 \\
(.013)\end{array}$ & & \\
\hline Male·\# Entreps on Panel & & & & & & $\begin{array}{l}-.015 \\
(.022)\end{array}$ & \\
\hline Male·\# Corp Execs on Panel & & & & & & & $\begin{array}{l}-.011 \\
(.024)\end{array}$ \\
\hline Male & $\begin{array}{l}-.007 \\
(.058)\end{array}$ & $\begin{array}{l}-.061 \\
(.083)\end{array}$ & $\begin{array}{l}-.061 \\
(.065)\end{array}$ & $\begin{array}{c}.019 \\
(.026)\end{array}$ & $\begin{array}{c}.032 \\
(.044)\end{array}$ & $\begin{array}{c}.037 \\
(.028)\end{array}$ & $\begin{array}{c}.033 \\
(.028)\end{array}$ \\
\hline Person Controls & $\mathrm{Y}$ & $\mathrm{Y}$ & $\mathrm{Y}$ & $\mathrm{Y}$ & $\mathrm{Y}$ & $\mathrm{Y}$ & $\mathrm{Y}$ \\
\hline Competition Controls & $\mathrm{Y}$ & $\mathrm{Y}$ & $\mathrm{Y}$ & $\mathrm{Y}$ & $\mathrm{Y}$ & $\mathrm{Y}$ & Y \\
\hline Year (cohort) FE & $\mathrm{Y}$ & $\mathrm{Y}$ & $\mathrm{Y}$ & $\mathrm{Y}$ & $\mathrm{Y}$ & $\mathrm{Y}$ & $\mathrm{Y}$ \\
\hline $\mathrm{N}$ & 964 & 964 & 964 & 964 & 964 & 964 & 964 \\
\hline$R^{2}$ & .060 & .140 & .098 & .09 & .097 & .097 & .098 \\
\hline
\end{tabular}

Note: This table shows placebo tests for the main result. In all cases we include the independent effect of the number of judges (e.g. \# VCs on Panel or \# Entreps on Panel) but do not report it to keep the table parsimonious. Column 1 shows the effect of the number of VCs on the probability that the participant founds a firm that does not receive $\mathrm{VC}$ backing. Column 2 shows the effect on working as an employee at a company that is VC-backed. Columns 3-7 repeat the main regression in Table 4 Panel 1 column 1 , but use the number of judges in categories besides VC. Corp. Exec. is an abbreviation of Corporate Executive. Person and Competition controls are as listed in the note to Table 4. Standard errors are clustered by panel. $*, * *$, and $* * *$ denote significance at the 10 percent, 5 percent, and 1 percent levels. 
Table 6: Relationship between NVC Scores, Gender, and VC-backed Entrepreneurship

\begin{tabular}{|c|c|c|c|c|c|c|}
\hline \multirow[t]{2}{*}{ Dependent variable: } & \multicolumn{2}{|c|}{$\begin{array}{c}\text { VC-backed } \\
\text { Entrepreneurship }\end{array}$} & \multicolumn{4}{|c|}{ Score in Panel } \\
\hline & $(1)$ & $(2)$ & (3) & $(4)$ & (5) & $(6)$ \\
\hline Score in Panel & $\begin{array}{c}.034^{* * *} \\
(.011)\end{array}$ & $\begin{array}{l}.022^{*} \\
(.011)\end{array}$ & & & & \\
\hline Male·\# VCs on Panel & & & & & $\begin{array}{l}.028 \\
(.064)\end{array}$ & $\begin{array}{c}.037 \\
(.064)\end{array}$ \\
\hline Male & & $\begin{array}{l}.023 \\
(.022)\end{array}$ & $\begin{array}{c}-.200^{* *} \\
(.082)\end{array}$ & $\begin{array}{c}-.230^{* * *} \\
(.079)\end{array}$ & $\begin{array}{l}-.270 \\
(.190)\end{array}$ & $\begin{array}{l}-.320^{*} \\
(.190)\end{array}$ \\
\hline \# VCs on Panel & & & & $\begin{array}{l}-.030 \\
(.040)\end{array}$ & $\begin{array}{l}-.005 \\
(.060)\end{array}$ & $\begin{array}{l}-.055 \\
(.061)\end{array}$ \\
\hline Person Controls & & $\mathrm{Y}$ & & $\mathrm{Y}$ & & $\mathrm{Y}$ \\
\hline Competition Controls & & $\mathrm{Y}$ & & $\mathrm{Y}$ & & $\mathrm{Y}$ \\
\hline Year (cohort) FE & $\mathrm{Y}$ & $\mathrm{Y}$ & $\mathrm{Y}$ & $\mathrm{Y}$ & $\mathrm{Y}$ & $\mathrm{Y}$ \\
\hline $\mathrm{N}$ & 964 & 964 & 964 & 964 & 964 & 964 \\
\hline$R^{2}$ & .057 & .096 & .033 & .170 & .034 & .170 \\
\hline
\end{tabular}

Note: Columns 1-2 of this table show the relationship between judge scores of a team (i.e. venture) in the NVC and whether the participant team member subsequently founded a VC-backed startup. Columns 3-4 show the relationship between participant gender and venture scores. Columns 5-6 examine whether this relationship differs depending on the number of VCs on the panel. Scores are the average of individual judge scores on the panel. They vary from 1 to 5 , with 5 being the best. Person and Competition controls are as listed in the note to Table 4 . Standard errors are clustered by venture. *, **, and $* * *$ denote significance at the 10 percent, 5 percent, and 1 percent levels. 
Table 7: Survey Response Predictors and Analysis

\begin{tabular}{|c|c|c|c|c|c|c|c|}
\hline \multirow{3}{*}{$\begin{array}{l}\text { Sample: } \\
\text { Dependent variable: }\end{array}$} & \multicolumn{2}{|c|}{ All } & \multicolumn{3}{|c|}{ Survey responders } & \multicolumn{2}{|c|}{$\begin{array}{l}\text { Survey responders who } \\
\text { reached out to VC judge }\end{array}$} \\
\hline & \multicolumn{2}{|c|}{$\begin{array}{l}\text { Responded to } \\
\text { Survey }\end{array}$} & \multicolumn{2}{|c|}{$\begin{array}{l}\text { Reached out to } \\
\text { VC Judge }\end{array}$} & \multirow{2}{*}{$\begin{array}{l}\text { VC Judge } \\
\text { Reached } \\
\text { Out } \\
\\
(5)\end{array}$} & \multirow{2}{*}{$\begin{array}{c}\text { VC-backed } \\
\text { Entrep. } \\
\\
(6)\end{array}$} & \multirow{2}{*}{$\begin{array}{l}\text { VC Judge } \\
\text { Responded } \\
\\
\text { (7) }\end{array}$} \\
\hline & $(1)$ & $(2)$ & $(3)$ & (4) & & & \\
\hline Male & $\begin{array}{c}.019 \\
(.027)\end{array}$ & $\begin{array}{c}.003 \\
(.027)\end{array}$ & $\begin{array}{l}.160^{* *} \\
(.066)\end{array}$ & $\begin{array}{l}.210^{* * *} \\
(.080)\end{array}$ & $\begin{array}{c}.028 \\
(.058)\end{array}$ & $\begin{array}{l}-.290 \\
(.360)\end{array}$ & $\begin{array}{c}.011 \\
(.150)\end{array}$ \\
\hline \# VCs on Panel & & $\begin{array}{l}-.004 \\
(.009)\end{array}$ & & $\begin{array}{l}-.033 \\
(.027)\end{array}$ & & $\begin{array}{l}-.075 \\
(.065)\end{array}$ & \\
\hline VC-backed Entrep. & & $\begin{array}{c}.047 \\
(.040)\end{array}$ & & $\begin{array}{c}.064 \\
(.100)\end{array}$ & & & \\
\hline Male $\#$ VCs on Panel & & & & & & $\begin{array}{c}.120 \\
(.087)\end{array}$ & \\
\hline Person Controls & & $\mathrm{Y}$ & & $\mathrm{Y}$ & & & \\
\hline Competition Controls & & $\mathrm{Y}$ & & $\mathrm{Y}$ & & & \\
\hline Year (cohort) FE & Y & $\mathrm{Y}$ & Y & Y & Y & & \\
\hline $\mathrm{N}$ & 964 & 964 & 172 & 172 & 172 & 45 & 45 \\
\hline$R^{2}$ & .032 & .068 & .130 & .320 & .044 & .041 & .000 \\
\hline
\end{tabular}

Note: Columns 1-2 of this table show predictors of responding to the survey (172/964 responded). Columns 3-4 examine whether reaching out to a judge varies by gender, among responders. Column 5 examines whether, among responders, judges are more likely to reach out to men. Column 6 examines whether, conditional on the participant reaching out to a judge, more VCs on a panel still have a differential effect by gender. Column 7 examines whether, conditional on the participant reaching out to a judge, judges respond more to men. Person and Competition controls are as listed in the note to Table 4. Standard errors are clustered by panel. *,**, and *** denote significance at the 10 percent, 5 percent, and 1 percent levels. 


\section{Appendix \\ (for Online Publication)}

Figure A.1: Do some sectors have more male participants and/or more VC judges?
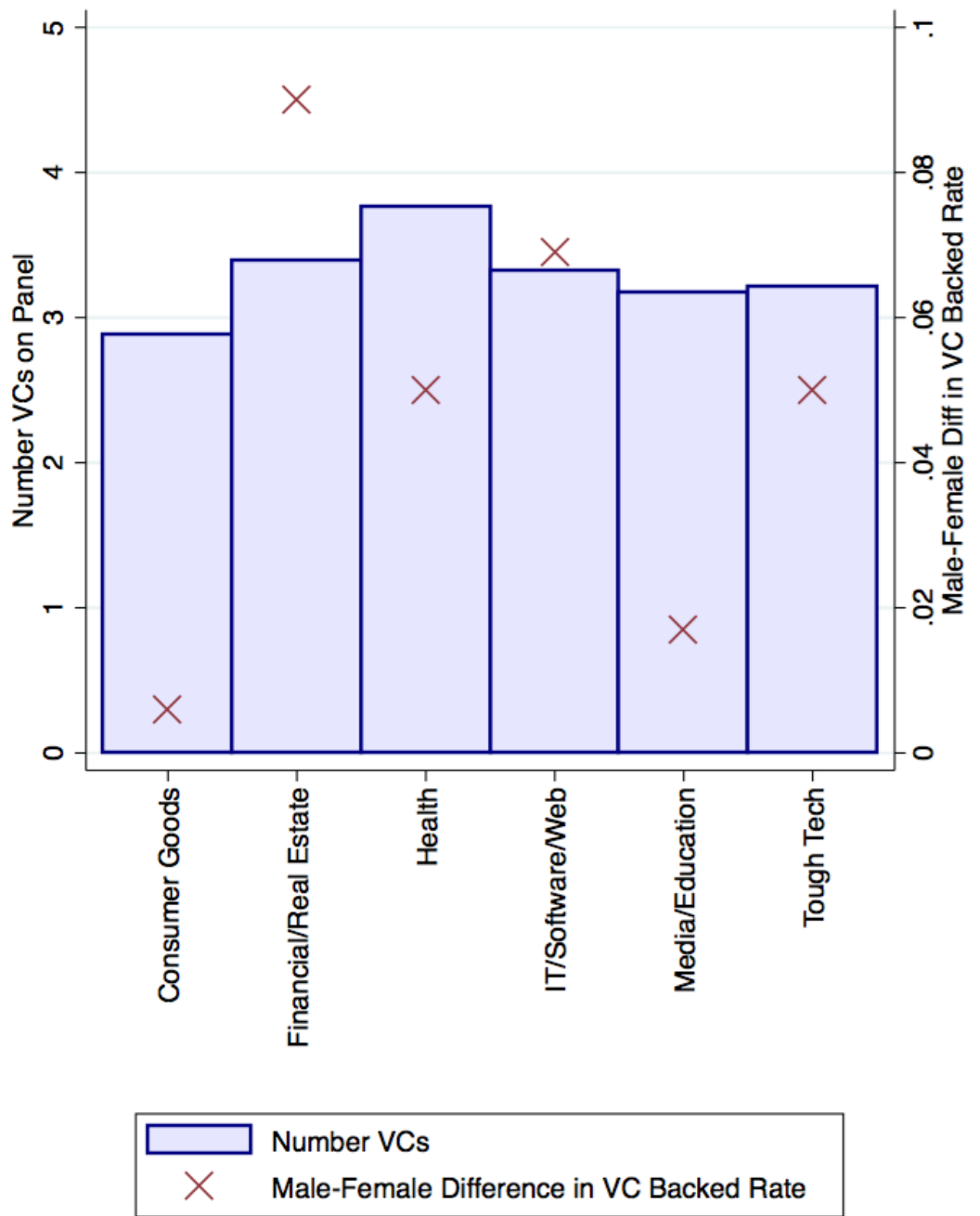

Note: This figure shows that sectors with relatively more male VC-backed entrepreneur participants do not also have relatively more VCs on the panel. The left axis shows the average number of VCs on the panel for companies in a given sector, such that the level of observation is the participant, and all 964 individuals in the HBS NVC are included. We use the number of VCs rather than the fraction on the panel because that is what is used in our primary empirical analysis. Results are qualitatively the same using the fraction on the panel. The right axis shows the difference by sector in the male and female rates of VC-backed entrepreneurship. That is, we calculate the chances that a participant in a given sector is of a certain gender and is a VC-backed entrepreneur. Then we subtract the female statistic from the male one. The number of participants in each sector is as follows: 187 in Consumer Goods, 33 in Financial/Real Estate, 100 in Health, 433 in IT/Software/Web, 66 in Media/Education, and 60 in Tough Tech. 


\section{Table A.1: Sector Composition}

\begin{tabular}{lccccccc}
\hline & \multicolumn{3}{c}{ Judges } & & \multicolumn{3}{c}{ Unique participants } \\
\cline { 2 - 3 } Sector & \multicolumn{2}{c}{ All } & VCs & & All & Female & Male \\
\hline \multirow{2}{*}{ IT/Software/Web } & & & & & & \\
Consumer Goods & 0.39 & 0.42 & & 0.45 & 0.45 & 0.52 \\
Health & 0.17 & 0.17 & & 0.19 & 0.28 & 0.18 \\
Media/Education & 0.15 & 0.16 & & 0.10 & 0.10 & 0.12 \\
Tough Tech (Tangible High Tech) & 0.19 & 0.30 & & 0.07 & 0.09 & 0.07 \\
Financial/Real Estate & 0.31 & 0.32 & & 0.03 & 0.02 & 0.04 \\
Total & 1,309 & 631 & & 964 & 289 & 590 \\
\hline \hline
\end{tabular}

Note: This table shows the probability that judges and participants are in each of six sectors. Note that judges may be in more than one sector, while participants may not. 10 percent of participants are not assigned a sector. "Tough tech" refers to tangible High Tech sectors, such as energy, biotech, manufacturing, defense, and electronics. 
Table A.2: Do males tend to face more VC judges in their own sector than females?

\begin{tabular}{|c|c|c|c|c|c|c|c|}
\hline \multirow[b]{2}{*}{ VC Judge Sector } & \multirow[b]{2}{*}{ Venture Sector } & \multicolumn{2}{|c|}{ Female participants } & \multicolumn{2}{|c|}{ Male participants } & \multirow[b]{2}{*}{ Diff } & \multirow[b]{2}{*}{ P-value } \\
\hline & & $\begin{array}{c}\text { \# female } \\
\text { participants } \\
\text { in sector }\end{array}$ & $\begin{array}{c}\text { Mean \# VC } \\
\text { judges on panel } \\
\text { this sector }\end{array}$ & $\begin{array}{l}\text { \# male } \\
\text { participants } \\
\text { in sector }\end{array}$ & $\begin{array}{c}\text { Mean \# VC } \\
\text { judges on panel } \\
\text { this sector }\end{array}$ & & \\
\hline IT/Software/Web & IT/Software/Web & 129 & 1.95 & 304 & 1.99 & -.04 & .80 \\
\hline Consumer Goods & Consumer Goods & 82 & .85 & 105 & .76 & .09 & .45 \\
\hline Health & Health & 30 & 2.47 & 70 & 2.29 & .18 & .56 \\
\hline Media/Education & Media/Education & 26 & 1.04 & 40 & 1.35 & -.31 & .29 \\
\hline Tough Tech & Tough Tech & 15 & 1.33 & 45 & 1.78 & -.44 & .26 \\
\hline Financial/Real Estate & Financial/Real Estate & 7 & 1.71 & 26 & 1.38 & .33 & .45 \\
\hline
\end{tabular}

Note: This table presents the difference in the means of the number of judges on panel in a certain sector conditional on the participant being in that sector, by gender of the participant. We first restrict the sample to consist only of ventures in a given sector, and then test whether males are more likely to have more VCs than females in their own sector. For example, in the first row, we restrict the sample to consist only of ventures in IT. We observe that women participants with an IT venture on average face 1.95 VC judges in IT. Male participants with an IT venture on average face $1.99 \mathrm{VC}$ judges in IT. The difference is not significant. "Tough tech" refers to tangible High Tech sectors, such as energy, biotech, manufacturing, defense, and electronics. 
Table A.3: Effect by VC Judge Characteristics

Dependent variable: VC-backed Entrepreneurship

(1)

$.027^{*}$

Male•\# Male VCs on Panel

Male·\# Female VCs on Panel

Male·\# VCs on Panel

Male

\# Male VCs on Panel

\# Female VCs on Panel

\# VCs on Panel

Judge invested

Person Controls
Competition Controls
Year (cohort) FE
$\mathrm{N}$
$R^{2}$

$\begin{array}{lccc} & & & .035^{* *} \\ & & & (.017) \\ -.075 & .031 & .035 & -.076 \\ (.048) & (.023) & (.026) & (.051)\end{array}$

$.027^{*}$

\begin{tabular}{cccc} 
& & -.025 \\
& & & $(.016)$ \\
& $.840^{* * *}$ \\
& & & \\
& & & \\
& & & \\
$\mathrm{Y}$ & & & $\mathrm{Y}$ \\
$\mathrm{Y}$ & & $\mathrm{Y}$ & \\
$\mathrm{Y}$ & $\mathrm{Y}$ & $\mathrm{Y}$ & \\
& & & \\
964 & 114 & 114 & 964 \\
.100 & .100 & .140 & .064 \\
\hline
\end{tabular}

Note: Column 1 of this table shows the effect of the number of male and female VCs on the probability that a male participant in the HBS NVC subsequently founds a VC-backed venture, relative to female participants. Note that on average a participant faces just 0.5 female $\mathrm{VCs}$, so half of panels have no female VCs and very few have more than one. (The average participant faces 2.1 male VCs.) Columns 2-3 examine whether gender predicts the judge or judge's firm investing in the venture (there are only 4 instances of this). Column 4 examines whether controlling for the judge investing affects the main result. Person and Competition controls are as listed in the note to Table 4. Standard errors are clustered by panel. $*, * *$, and $* * *$ denote significance at the 10 percent, 5 percent, and 1 percent levels. 
Table A.4: Effect of VC Judges on Subsequent VC-backed Entrepreneurship by Gender and VC Stage

\begin{tabular}{|c|c|c|c|}
\hline \multicolumn{4}{|c|}{ Dependent variable: VC-backed Entrepreneurship } \\
\hline & (1) & $(2)$ & (3) \\
\hline Male·\# Early VCs & $\begin{array}{l}.055^{*} \\
(.031)\end{array}$ & & \\
\hline Male·\# Late VCs & & $\begin{array}{l}-.011 \\
(.038)\end{array}$ & \\
\hline $\begin{array}{l}\text { Male } \# \text { \# Not Specialized } \\
\text { VCs }\end{array}$ & & & .023 \\
\hline & & & $(.022)$ \\
\hline Male & $\begin{array}{l}-.004 \\
(.025)\end{array}$ & $\begin{array}{l}-.033 \\
(.025)\end{array}$ & $\begin{array}{l}-.007 \\
(.030)\end{array}$ \\
\hline \# Early VCs & $\begin{array}{l}-.041 \\
(.025)\end{array}$ & & \\
\hline \# Late VCs & & $\begin{array}{l}-.021 \\
(.037)\end{array}$ & \\
\hline \# Not Specialized VCs & & & $\begin{array}{l}-.013 \\
(.018)\end{array}$ \\
\hline Person Controls & $\mathrm{Y}$ & Y & $\mathrm{Y}$ \\
\hline Competition Controls & $\mathrm{Y}$ & $\mathrm{Y}$ & Y \\
\hline Year (cohort) FE & $\mathrm{Y}$ & $\mathrm{Y}$ & $\mathrm{Y}$ \\
\hline $\mathrm{N}$ & 964 & 964 & 964 \\
\hline$R^{2}$ & .091 & .090 & .090 \\
\hline
\end{tabular}

Note: This table shows the effect of the number of venture capitalists (VCs) and the stages of VCs on the probability that a male participant in the HBS NVC subsequently founds a VC-backed venture, relative to female participants. Person controls consist of the following indicator variables: Interest in entrepreneurship, interest in finance, interest in management, entrepreneurship or VC clubs membership at HBS, previous VC-backed entrepreneurship experience, previous work for a VC-backed startup, previous work for a VC firm, previous non-VC backed entrepreneurship, honors at HBS, US citizen, computer science college major, engineering college major, economics/business/management college major, and college degree from an Ivy + university. Competition controls consist of the following: The venture score in the panel, indicator for winning the competition (overall or runner-up), the number of ventures on the panel, the number of male judges on the panel, and the number of total judges on the panel. Standard errors are clustered by panel. *, **, and *** denote significance at the 10 percent, 5 percent, and 1 percent level. 
Table A.5: Effect of VC Judges on Startup Outcomes Conditional on VC-backed Entrepreneurship

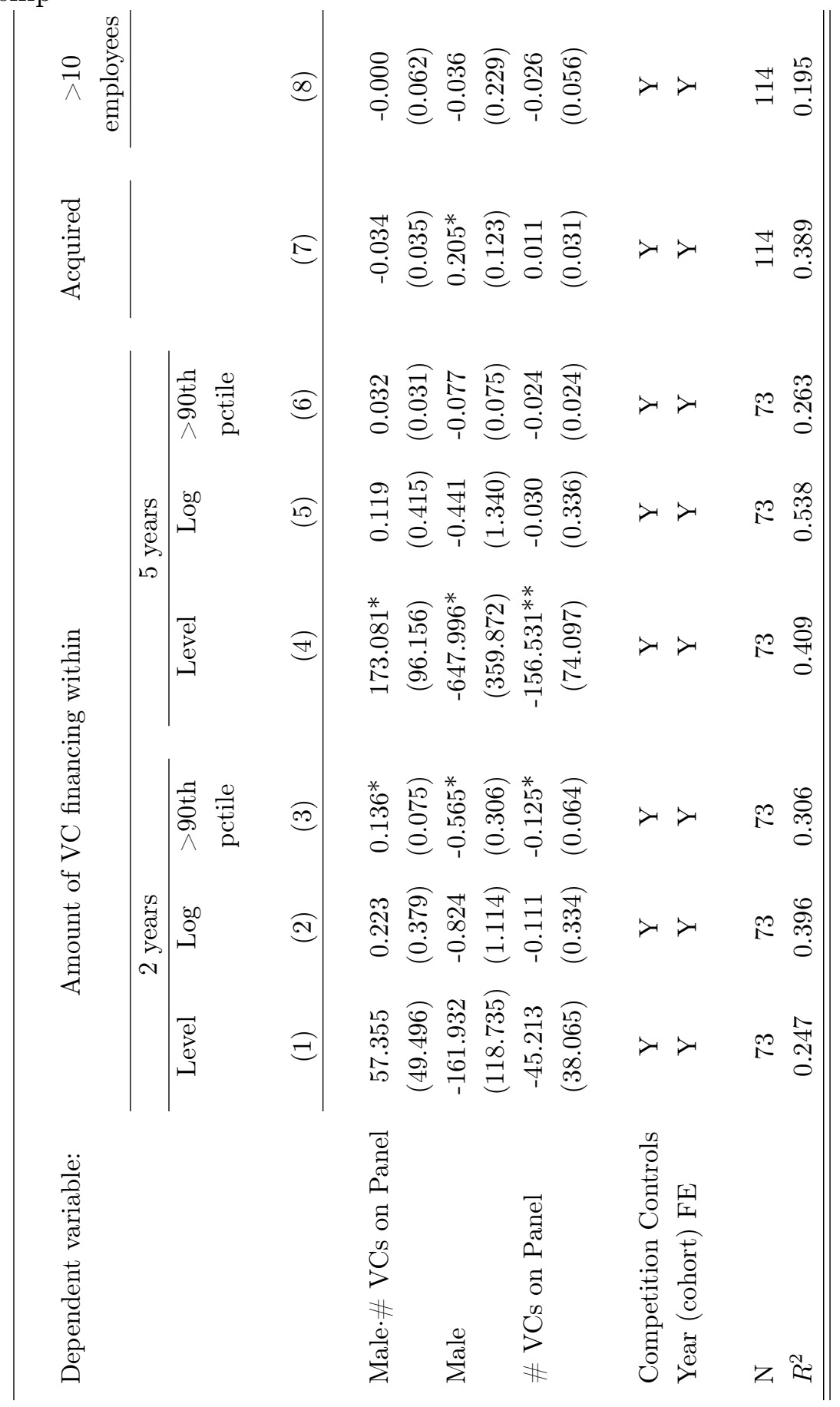

Note: This table examines the effect of VC judges on the panel within the sample of 114 VC-backed startups founded by participants. There is funding amount data available for 73 of these startups. Competition controls are as listed in the note to Table 4. No person controls are included due to the small sample. Standard errors are clustered by panel. *,**, and *** denote significance at the 10 percent, 5 percent, and 1 percent levels. 
Table A.6: Effect of VC Judges on VC-backed Entrepreneurship by Other Characteristics

Panel 1: Pre-HBS Professional Experience

Dependent variable: VC-backed Entrepreneurship

$(3)$

(4)

$(5)$

Pre-VC-bckd Entrep. \# VCs on Panel

Pre-non-VC-bckd Entrep. \# VCs on Panel .027

$(.025)$

Pre-VC-bckd Co Emp·\# VCs on Panel

$-.014$

$(.014)$

Pre-VC Firm Emp·\# VCs on Panel

.051

$(.038)$

Pre-Consultant Emp.•\# VCs on Panel

$-.015$

$(.016)$

Pre-Finance Emp.*\# VCs on Panel

Pre-VC-backed Entrep. $-.028$

Pre-non-VC-backed Entrep.

$-.031$

$(.076)$

Pre-VC-backed Co Employment

.038

$(.048)$

Pre-VC Firm Employment $-.17$

Pre-Consultant Employment

(.050)

Pre-Finance Employment

.012

\# VCs on Panel

$\begin{array}{cccccc}.009 & .006 & .017 & .010 & .016 & .009 \\ (.008) & (.010) & (.013) & (.009) & (.010) & (.010)\end{array}$

Year (cohort) FE $\begin{array}{lllllll}\mathrm{Y} & \mathrm{Y} & \mathrm{Y} & \mathrm{Y} & \mathrm{Y} & \mathrm{Y}\end{array}$

$\mathrm{N}$

$\begin{array}{llllll}964 & 964 & 964 & 964 & 964 & 964\end{array}$

$R^{2}$ .052 .055 .048 .050 .050

Note: This panel shows the effect of the number of venture capitalists (VCs) on the probability that a participant in the HBS NVC subsequently founds a VC-backed venture by pre-HBS professional experience. Standard errors are clustered by panel. $*, * *$, and $* * *$ denote significance at the 10 percent, 5 percent, and 1 percent levels.

Online Appendix 
Panel 2: Education and NVC Win Status

Dependent variable: VC-backed Entrepreneurship

(1)

Ivy + BA·\# VCs on Panel

HBS Honors·\# VCs on Panel

Comp Sci Major·\# VCs on Panel

Engineering Major·\# VCs on Panel

Econ or Business Major·\# VCs on Panel

Round Winner·\# VCs on Panel

$\mathrm{Ivy}+\mathrm{BA}$

\section{HBS Honors}

Comp Sci Major

Engineering Major

Econ or Business Major

Round Winner

\# VCs on Panel

Year (cohort) FE

$\mathrm{N}$

$R^{2}$

$-.023$
$(.015)$ $-.025$

(.024)

.028

(.026)

.0048

(.018)

$.034^{*}$

(.019)

-.018

(.022)

$.100 *$

(.053)

.100

(.079)

$-.059$

(.092)

$-.055$

(.056)

\begin{tabular}{cccccc} 
& & & & -.084 & \\
& & & & $(.069)$ & \\
& & & & & $.170^{* *}$ \\
& & & & & $(.083)$ \\
$.020^{*}$ & $.016^{*}$ & .010 & .012 & .003 & $.017^{*}$ \\
$(.011)$ & $(.009)$ & $(.009)$ & $(.011)$ & $(.010)$ & $(.010)$ \\
& & & & & \\
$\mathrm{Y}$ & $\mathrm{Y}$ & $\mathrm{Y}$ & $\mathrm{Y}$ & $\mathrm{Y}$ & $\mathrm{Y}$ \\
& & & & & \\
964 & 964 & 964 & 964 & 964 & 964 \\
.052 & .050 & .049 & .050 & .054 & .066 \\
\hline
\end{tabular}

Note: This panel shows the effect of the number of venture capitalists (VCs) on the probability that a participant in the HBS NVC subsequently founds a VC-backed venture. We interact the number of VCs with education-related variables in Columns 1-5, and with winning the round in Column 6. Standard errors are clustered by panel. *, **, and $* * *$ denote significance at the 10 percent, 5 percent, and 1 percent levels. 
Table A.7: Sample Splits in Effect of VCs on VC-backed Entrepreneurship by Gender

\begin{tabular}{|c|c|c|c|c|}
\hline Sample: & $\leq 2010$ & $>2010$ & $\begin{array}{c}\# \text { ventures } \\
\text { on panel } \leq 5\end{array}$ & $\begin{array}{c}\# \text { ventures } \\
\text { on panel } \geq 5\end{array}$ \\
\hline & $(1)$ & $(2)$ & $(3)$ & $(4)$ \\
\hline Male.\# VCs on Panel & $\begin{array}{c}.021 \\
(.025)\end{array}$ & $\begin{array}{l}.044^{* *} \\
(.017)\end{array}$ & $\begin{array}{l}.028^{* *} \\
(.014)\end{array}$ & $\begin{array}{l}.043^{* *} \\
(.019)\end{array}$ \\
\hline Male & $\begin{array}{l}-.066 \\
(.097)\end{array}$ & $\begin{array}{l}-.089 * \\
(.053)\end{array}$ & $\begin{array}{l}-.067 \\
(.047)\end{array}$ & $\begin{array}{l}-.092 \\
(.064)\end{array}$ \\
\hline \# VCs on Panel & $\begin{array}{l}-.010 \\
(.021)\end{array}$ & $\begin{array}{l}-.019 \\
(.013)\end{array}$ & $\begin{array}{r}-.0099 \\
(.011)\end{array}$ & $\begin{array}{l}-.019 \\
(.016)\end{array}$ \\
\hline Person Controls & $\mathrm{Y}$ & $\mathrm{Y}$ & $\mathrm{Y}$ & $\mathrm{Y}$ \\
\hline Competition Controls & $\mathrm{Y}$ & $\mathrm{Y}$ & $\mathrm{Y}$ & $\mathrm{Y}$ \\
\hline Year (cohort) FE & $\mathrm{Y}$ & $\mathrm{Y}$ & $\mathrm{Y}$ & $\mathrm{Y}$ \\
\hline $\mathrm{N}$ & 549 & 415 & 890 & 657 \\
\hline$R^{2}$ & .110 & .150 & .110 & .120 \\
\hline
\end{tabular}

Note: This table shows the effect of the number of VCs on the probability that a participant in the HBS NVC subsequently founds a VC-backed venture using alternative samples. Columns 1 and 2 split the sample roughly in half by year of the NVC. Columns 3 and 4 split the sample by the number of ventures in the panel. Five ventures are included in both groups because the majority (583) of observations have five ventures per panel. We find no effect when we exclude panels with five ventures. Competition and Person controls are as listed in the note to Table 4. Standard errors are clustered by panel. *, **, and *** denote significance at the 10 percent, 5 percent, and 1 percent levels. 